\title{
Natural regeneration in a mixed ombrophilous forest remnant in southern Brazil
}

\section{Regeneração natural em remanescente de floresta ombrófila mista no sul do Brasil}

\author{
Manuela Gazzoni dos Passos ${ }^{1}$, Geisa Percio do Prado ${ }^{1}$, Claudia Fontana ${ }^{2}$, \\ Edilvane Ines Zonta ${ }^{1}$, Edmilson Bianchini ${ }^{3}$
}

1 Universidade do Oeste de Santa Catarina, Campus Chapecó, Av. Nereu Ramos, 3777D, Chapecó, CEP 89801-000, SC, Brazil

2 Universidade de São Paulo, Colégio de Agricultura Luiz de Queiroz, Departamento de Ciências Florestais. Avenida Pádua Dias, 11, Caixa Postal 9, Piracicaba, CEP 13418-900, SP, Brazil

3 Programa de Pós Graduação em Ciências Biológicas, Universidade Estadual de Londrina, Campus

Universitário, Caixa Postal 10011, Londrina, CEP 86057-970, PR, Brazil

Corresponding author: Manuela Gazzoni dos Passos (biologamanu@gmail.com)

Academic editor: A.M. Leal-Zanchet | Received 4 September 2020 | Accepted 1 February 2021 | Published 2 March 2021

Citation: Passos MG, Prado GP, Fontana C, Zonta EI, Bianchini E (2021) Natural regeneration in a mixed ombrophilous forest remnant in southern Brazil. Neotropical Biology and Conservation 16(1): 167-183. https://doi. org/10.3897/neotropical.16.e58188

\begin{abstract}
The study of forest regeneration allows the diagnosis of conservation status of fragments and estimating population parameters that are essential for management projects. This study evaluated the structure, diversity and dynamics of the tree regenerating component of a remnant of mixed ombrophilous forest, aiming to support management actions for this forest type. The study was developed at the Parque Estadual das Araucárias (PEAR), located in the western region of the state of Santa Catarina, southern Brazil. A total of 100 plots of $25 \mathrm{~m}^{2}(0.25 \mathrm{ha})$ were allocated, all individuals with height $\geq$ $1.0 \mathrm{~m}$ and $\mathrm{DBH}<5 \mathrm{~cm}$ were sampled. Shannon's diversity index ( $\left.\mathrm{H}^{\prime}\right)$, Pielou's equability index (J) and total natural regeneration rate (TNR) were estimated. We sampled 1,425 individuals from 99 species and 39 families, with an estimated total density of 5,700 individuals by hectare. The richest families were Fabaceae (13), Myrtaceae (10) and Lauraceae (7). The H' was 3.76 and the J was 0.80 . The TNR rate ranged from 0.05 to $8.12 \%$, highlighting Trichilia elegans, with the highest rate and Araucaria
\end{abstract}


angustifolia with low potential for natural regeneration. The analysis of the results indicated a high diversity in the regenerating component of the PEAR compared to other studies, probably because the area presents itself as a successional mosaic due to past disturbances.

\section{Resumo}

O estudo da regeneração florestal permite diagnosticar o estado de conservação de fragmentos florestais e estimar os parâmetros populacionais que são imprescindíveis para o manejo florestal. Este estudo avaliou a estrutura, a diversidade e a dinâmica do componente regenerante arbóreo de um remanescente de floresta ombrófila mista, visando dar suporte cientifico às ações de gestão e manejo para este tipo florestal. O estudo foi desenvolvido no Parque Estadual das Araucárias (PEAR), localizado na região oeste de Santa Catarina, sul do Brasil. Foram alocadas 100 parcelas de $25 \mathrm{~m}^{2}$ ( $0.25 \mathrm{ha}$ ) e, nestas, foram amostrados todos os indivíduos com altura maior ou igual a $1.0 \mathrm{~m}$ e diâmetro à altura do peito menor que $5 \mathrm{~cm}$. Foram estimados os índices de diversidade de Shannon ( $\left.\mathrm{H}^{\prime}\right)$ e de equabilidade de Pielou (J) e a taxa de regeneração natural total (RNT). Foram amostrados 1.425 indivíduos pertencentes a 99 espécies e 39 famílias botânicas, com densidade total estimada de 5.700 indivíduos por hectare. As famílias com maior riqueza foram Fabaceae (13), Myrtaceae (10) e Lauraceae (7). O H’ foi de 3.76 e o J foi de 0.80. A taxa RNT variou de 0.05 a 8.12\%, com destaque para Trichilia elegans, com a maior taxa de regeneração natural e Araucaria angustifolia com baixo potencial de regeneração natural. A análise dos resultados indicou alta diversidade no componente regenerante do PEAR, provavelmente em razão da área se apresentar como um mosaico sucessional em razão de perturbações pretéritas.

\section{Keywords}

Araucaria, Atlantic forest, biodiversity, conservation, disturbance, heterogeneity, tree species

\section{Palavras-chave}

Araucaria, biodiversidade, conservação, espécies arbóreas, heterogeneidade, mata atlântica, perturbação

\section{Introduction}

Natural regeneration is related to the ability of species to establish and develop after natural or anthropic disturbances (Marchesini et al. 2009). The analysis of this process allows the assessment of the conservation status of fragments and the estimation of population parameters, which are essential for sustainable forest management (Silva et al. 2010a; Higuchi et al. 2015; Santos et al. 2015).

The forests of the state of Santa Catarina (SC) were greatly impacted by human action (Gasper et al. 2013). In the western region of SC, the mixed ombrophilous forest (MOF), also called Araucaria forest because Araucaria angustifolia (Bertol.) Kuntze is a characteristic element of this forest type, and seasonal deciduous forest (SDF) remnants are in a critical state of conservation, with altered structure and predominance of secondary and pioneer species (Schorn et al. 2013). Although the physiognomy might suggest some uniformity in the MOF within its natural range, floristic and phytosociological surveys reveal particular distinctions among MOF remnants (Jarenkow and Budke 2009). For example, a strong association between A. angustifolia, and Ocotea porosa (Nees \& Mart.) Barroso was observed in 
the northern plateau of SC (Klein 1978) whereas a greater association between $A$. angustifolia with O. pulchella (Ness \& Mart.) Mez and O. puberula (Rich.) Nees was recorded for the southern plateau (Klauberg et al. 2010; Martins et al. 2012; Higuchi et al. 2013). Therefore, knowledge about natural regeneration can be of great importance to support strategies for the conservation of forest remnants, and the restoration of degraded environments, especially in the western region of SC.

Some studies on natural regeneration of MOF have been developed in SC (e.g. Caldato et al. 1996; Meyer et al. 2013; Fiorentin et al. 2015; Higuchi et al. 2015; Santos et al. 2015; Maçaneiro et al. 2016; Rosa et al. 2016; Duarte et al. 2019; Vefago et al. 2019). Caldato et al. (1996) found that, although Araucaria angustifolia was the dominant species in the forest canopy, it did not show individuals in natural regeneration. In the Inventário Florístico Florestal de Santa Catarina (IFFSC), which evaluated plots of natural regeneration throughout SC (Meyer et al. 2013), a remarkable presence of SDF tree species was recorded in the plots allocated in altitudes below $1000 \mathrm{~m}$, possibly because they are transition areas between MOF and SDF. In plots allocated at altitudes between 1000 and $1200 \mathrm{~m}$, A. angustifolia was recorded as the species with the highest importance value (Meyer et al. 2013). Fiorentin et al. (2015) evaluated the effect of livestock on the composition and floristic diversity of natural regeneration in areas of permanent preservation of MOF, and found that Myrtaceae had the largest number of individuals and species. This was also observed by Santos et al. (2015) in a fragment of MOF, although the species with the highest Importance Value Index (IVI) was Myrsine parvula (Mez) Otegui (Primulaceae). Maçaneiro et al. (2016) evaluated the tree and shrub natural regeneration in an MOF fragment and found that Allophylus edulis (A.St.-Hil. et al.) Hieron. ex Niederl, Casearia decandra Jacq., Cupania vernalis Cambess., Matayba elaeagnoides Radlk. and Myrsine coriacea (Sw.) R.Br. ex Roem. \& Schult had the highest rates of relative natural regeneration. Although the IFFSC contemplated plots in the western region, all other studies were carried out in the midwest and south of SC, with a gap in knowledge about the natural regeneration of MOF in western SC.

Passos et al. (2021) studied the tree community in a MOF remnant in the western region of SC and recorded the occurrence of 106 species. Nectandra megapotamica (Spreng.) Mez, A. angustifolia, Ocotea diospyrifolia (Meisn.) Mez, Luehea divaricata Mart. and Ilex paraguariensis A.St.-Hil. showed the highest IVI. The authors also observed the association of $A$. angustifolia and N. megapotamica and absence of Drimys spp. and Podocarpus spp. Secondary (63\%) and zoochorous (71\%) species were the majority in the forest remnant (Passos et al. 2021). This study investigated the structure and diversity of regenerating tree species in this same MOF remnant, aiming to answer the questions: Is the similarity between the regenerating and the tree components high? Do secondary and zoochorous species predominate in sampling? Are the species with the highest regeneration rates among those with the highest IVI in the tree survey? 


\section{Material and methods}

The study was carried out at Parque Estadual das Araucárias (PEAR - 26 27'08"S, $52^{\circ} 33^{\prime} 56^{\prime \prime W}$ ), western SC, southern Brazil. This protected area (612 ha), created in May 2003, was previously used for the extraction and processing of wood, especially of Araucaria angustifolia.

According to the Köppen classification, the region's climate is of the $\mathrm{Cfb}$ type - with mild summers (Alvares et al. 2013). Temperatures in the coldest month range from $-3{ }^{\circ} \mathrm{C}$ to $18{ }^{\circ} \mathrm{C}$ and those in the hottest month are over $22^{\circ} \mathrm{C}$. The average annual rainfall in western SC is approximately $2,400 \mathrm{~mm}$ (Santa Catarina 1986).

On a PEAR map 100 plots of $100 \mathrm{~m}^{2}(10 \mathrm{~m} \times 10 \mathrm{~m})$ were allocated, seeking to represent all areas of the PEAR, but avoiding those that are difficult to access or particularly degraded (Passos et al. 2021). These plots were later demarcated in the field. The sampling of the tree regenerating component was carried out in the rightupper quadrant $(5 \mathrm{~m} \times 5 \mathrm{~m})$, totaling 0.25 ha. In each quadrant, all individuals of tree species with height $\geq 1.0 \mathrm{~m}$ and diameter at breast height $(\mathrm{DBH})<5 \mathrm{~cm}$ were sampled, measured (height and DBH) and identified (Silva et al. 2010b). The definition of the upper limit was based on the inclusion criterion $(\mathrm{DBH} \geq 5.0 \mathrm{~cm}) \mathrm{most}$ commonly used in surveys of tree canopy species in tropical forest (e.g. Klauberg et al. 2010; Higuchi et al. 2013; Passos et al. 2021). For individuals not identified in the field, the collection and herborization of plant material was carried out for later identification through comparison with FURB herbarium specimens and assistance from specialists. The vouchers were deposited at FUEL herbarium (acronyms according to Thiers 2021). The families were classified according to APG IV (APG 2016) and the list of species is in agreement with Flora do Brasil 2020 (Flora do Brasil 2020).

We used the rarefaction curve and Jackknife 2 method in order to compare the observed richness with the estimated richness (Oliveira et al. 2016), using the ESTIMATES 9.1.0 program (Colwell 2013), after 100 randomizations of the order of the samples with a 95\% confidence interval. Shannon's diversity and Pielou's equability indexes were also calculated using the MATA NATIVA 2 program (Cientec 2006). We used the Sorensen index to assess the similarity between the tree (Passos et al. 2021) and regenerating components. The species were classified according to the dispersal syndrome (Van der Pijl 1982) and according to the successional group in, pioneer, secondary or climax (Backes and Irgang 2002; Lorenzi 2008; Meyer et al. 2013).

The density and frequency (absolute and relative) of each species were calculated according to Mueller-Dombois and Ellenberg (1974), through the program MATA NATIVA 2 (Cientec 2006). Subsequently, the individuals were classified into three size classes: 1 - height between $1.0 \mathrm{~m}$ and $2.0 \mathrm{~m} ; 2$ - height between $2.01 \mathrm{~m}$ and $3.0 \mathrm{~m}$; and class 3 - height above $3.0 \mathrm{~m}$ and $\mathrm{DBH}<5 \mathrm{~cm}$ (Silva et al. 2010b). The absolute and relative parameters of frequency and density of each species in relation to each size-class were recalculated. 
The species' natural regeneration rate by size class (NRC) was estimated by the equation $\mathrm{NRC}=\mathrm{RD}+\mathrm{RF} / 2$ (Silva et al. 2010b), where $\mathrm{RD}=$ relative density of the species in the size class considered; and $\mathrm{RF}=$ relative frequency of the species in that size class. Then, the potential total natural regeneration rate for each species (TNR) was obtained by equation $\mathrm{TNR}=\Sigma(\mathrm{NRC}) / \mathrm{z}$ (Volpato 1994), where $\mathrm{z}=$ number of size classes.

\section{Results}

A total of 1,425 individuals belonging to 99 species distributed in 39 families were sampled, corresponding to an overall density of 5,700 individuals per hectare. The analysis of the rarefaction curve shows that the observed richness was less than the richness estimated by the Jackknife2 estimator, indicating that the species richness may be greater than that sampled (Fig. 1).

The families with the highest species richness were Fabaceae (13), Myrtaceae (10), Lauraceae (7), Sapindaceae, Salicaceae and Meliaceae (5), which together represented $46.6 \%$ of the total species.

Natural regeneration in the PEAR showed a Shannon diversity index of 3.76 nats ind. ${ }^{-1}$ and a Pielou equability index of 0.8 . The species with the highest density were Nectandra megapotamica, Coussarea contracta (Walp.) Müll.Arg., Trichilia elegans A.Juss., Cupania vernalis and Cestrum bracteatum Link \& Otto, which accounted for $29.3 \%$ of the total absolute density of regenerants (Table 1 ). These species, together with Matayba elaeagnoides, were the ones with the highest frequency of occurrence, and together, they represented $28.74 \%$ of the total frequency (Table 1 ). No regenerating individuals of exotic species were registered in the present study, although adult individuals of Citrus sp. and Hovenia dulcis Thunb. have been observed.

Of the 99 species sampled, 18\% (18 spp.) are considered rare in the PEAR because they have only one individual. The regenerating component showed high floristic similarity with the tree component (Sorensen similarity index $=0.79$ ). Species

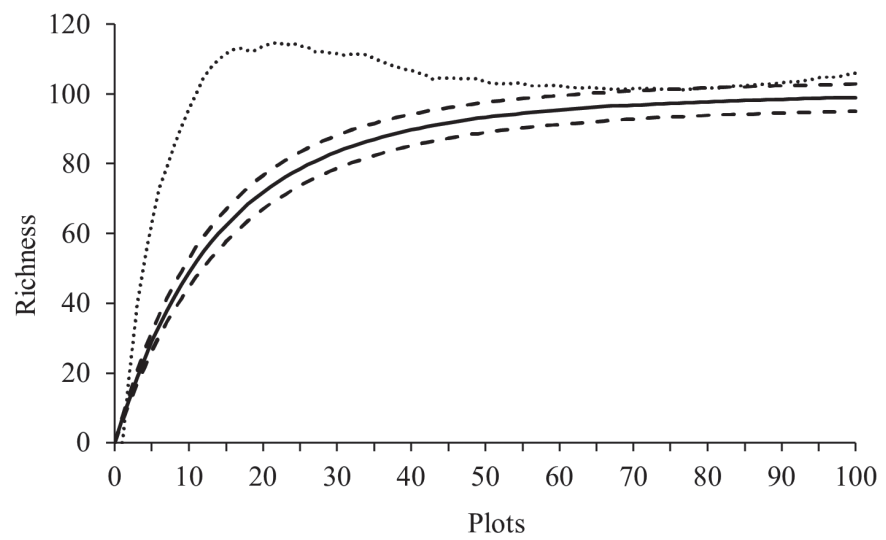

Figure 1. Species richness in the tree regenerating component of the Parque Estadual das Araucárias, Santa Catarina, southern Brazil. Solid line $=$ observed richness; Dashed lines $=95 \%$ confidence interval; Dotted line $=$ species richness estimated by the estimator Jacknife2. 
Table 1. Regenerating tree species sampled at the Parque Estadual das Araucárias, Santa Catarina, southern Brazil. $\mathrm{N}=$ number of individuals sampled; $\mathrm{SG}=$ successional group $(\mathrm{P}=$ pioneer, $\mathrm{S}=$ secondary, $\mathrm{C}=$ clímax $)$; $\mathrm{DS}=$ dispersal syndrome $(\mathrm{Z}=$ zoochory, $\mathrm{A}=$ anemochory, $\mathrm{Au}=$ autochory); $\mathrm{AD}=$ absolute density (ind ha ${ }^{-1}$ ); $\mathrm{RD}=$ relative density (\%); $\mathrm{AF}=$ absolute frequency (\%); RF = relative frequency (\%); NRC1, NRC2, NRC3 (\%) = natural regeneration rate in classes 1, 2 and 3 , respectively; $\mathrm{TNR}=$ potential total natural regeneration rate.

\begin{tabular}{|c|c|c|c|c|c|c|c|c|c|c|c|}
\hline Species & $\mathbf{N}$ & SG & DS & AD & RD & AF & RF & NRC1 & NRC2 & NRC3 & TNR \\
\hline Nectandra megapotamica (Spreng.) Mez & 119 & $\mathrm{~S}$ & $\mathrm{Z}$ & 476 & 8.35 & 36 & 5.22 & 7.65 & 6.87 & 6.89 & 7.14 \\
\hline Coussarea contracta (Walp.) Mull.Arg. & 109 & $\mathrm{P}$ & $\mathrm{Z}$ & 436 & 7.65 & 30 & 4.35 & 5.83 & 6.40 & 8.59 & 6.94 \\
\hline Trichilia elegans A.Juss & 103 & S & $\mathrm{Z}$ & 412 & 7.23 & 36 & 5.22 & 4.95 & 8.84 & 10.57 & 8.12 \\
\hline Cupania vernalis Cambess. & 86 & $\mathrm{P}$ & $\mathrm{Z}$ & 344 & 6.04 & 36 & 5.22 & 5.95 & 5.38 & 7.64 & 6.33 \\
\hline Cestrum bracteatum Link \& Otto & 69 & $\mathrm{~S}$ & $\mathrm{Z}$ & 276 & 4.84 & 30 & 4.35 & 4.41 & 4.45 & 5.86 & 4.90 \\
\hline Matayba elaeagnoides Radlk. & 57 & $\mathrm{~S}$ & $\mathrm{Z}$ & 228 & 4.00 & 30 & 4.35 & 5.35 & 3.42 & 1.83 & 3.53 \\
\hline Ocotea diospyrifolia (Meisn.) Mez & 51 & $\mathrm{C}$ & $\mathrm{Z}$ & 204 & 3.58 & 24 & 3.48 & 1.50 & 1.91 & 3.04 & 2.15 \\
\hline Luehea divaricata Mart. & 49 & $\mathrm{~S}$ & A & 196 & 3.44 & 16 & 2.32 & 2.22 & 2.94 & 5.55 & 3.57 \\
\hline Nectandra grandiflora Ness & 49 & S & $\mathrm{Z}$ & 196 & 3.44 & 8 & 1.16 & 2.46 & 3.60 & 0.91 & 2.32 \\
\hline Casearia decandra Jacq. & 45 & $\mathrm{~S}$ & $\mathrm{Z}$ & 180 & 3.16 & 23 & 3.34 & 3.08 & 3.30 & 3.58 & 3.32 \\
\hline Parapiptadenia rigida (Benth.) Brenan. & 43 & $\mathrm{~S}$ & A & 172 & 3.02 & 24 & 3.48 & 3.58 & 2.48 & 2.74 & 2.94 \\
\hline Allophylus edulis (A.St.-Hil. et al.) Hieron. ex Niederl & 34 & $S$ & $\mathrm{Z}$ & 136 & 2.39 & 15 & 2.18 & 2.10 & 2.84 & 2.40 & 2.45 \\
\hline Allophylus guaraniticus (A.St.-Hil.) Radlk. & 32 & $\mathrm{C}$ & $\mathrm{Z}$ & 128 & 2.25 & 18 & 2.61 & 2.21 & 3.05 & 2.28 & 2.52 \\
\hline Prunus myrtifolia (L.) Urb. & 30 & $\mathrm{~S}$ & $\mathrm{Z}$ & 120 & 2.11 & 14 & 2.03 & 2.09 & 1.60 & 3.58 & 2.42 \\
\hline Sorocea bonplandii (Bail.) W.C.Burger, Lanj. \& Boer & 30 & S & $\mathrm{Z}$ & 120 & 2.11 & 10 & 1.45 & 1.63 & 1.39 & 2.58 & 1.87 \\
\hline Campomanesia xanthocarpa (Mart.) O.Berg & 29 & S & $\mathrm{Z}$ & 116 & 2.04 & 21 & 3.05 & 3.02 & 1.81 & 0.46 & 1.76 \\
\hline Diatenopteryx sorbifolia Radlk. & 29 & $\mathrm{P}$ & $\mathrm{Z}$ & 116 & 2.04 & 21 & 3.05 & 2.62 & 1.91 & 1.56 & 2.03 \\
\hline Ocotea puberula (Rich.) Nees & 29 & $\mathrm{P}$ & A & 116 & 2.04 & 11 & 1.60 & 0.93 & 1.24 & 0.46 & 0.88 \\
\hline Trichilia clausseni C.DC. & 25 & $\mathrm{~S}$ & $\mathrm{Z}$ & 100 & 1.75 & 15 & 2.18 & 1.69 & 3.05 & 2.28 & 2.34 \\
\hline Urera baccifera (L.) Gaudich. ex Wedd. & 21 & $\mathrm{~S}$ & $\mathrm{Z}$ & 84 & 1.47 & 15 & 2.18 & 2.47 & 0.73 & 0.00 & 1.07 \\
\hline Cinnamomum amoenum (Ness \& Mart). Kosterm. & 19 & $\mathrm{~S}$ & Z & 76 & 1.33 & 6 & 0.87 & 1.13 & 0.88 & 1.56 & 1.19 \\
\hline Ilex paraguariensis A.St.-Hil. & 17 & $\mathrm{P}$ & Z & 68 & 1.19 & 9 & 1.31 & 0.61 & 2.64 & 1.37 & 1.54 \\
\hline Actinostemon concolor (Spreng.) Müll.Arg. & 16 & $\mathrm{C}$ & $\mathrm{Au}$ & 64 & 1.12 & 1 & 0.15 & 0.82 & 0.67 & 0.46 & 0.65 \\
\hline Muellera campestris (Mart. ex Benth.) M.J.Silva \& A.M.G.Azevedo & 16 & $\mathrm{~S}$ & A & 64 & 1.12 & 10 & 1.45 & 1.70 & 0.73 & 0.46 & 0.96 \\
\hline Sebastiania commersoniana (Baill.) L.B.Sm. \& Downs & 16 & $\mathrm{P}$ & $\mathrm{Au}$ & 64 & 1.12 & 7 & 1.02 & 1.01 & 1.24 & 0.91 & 1.05 \\
\hline Syagrus romanzoffiana (Cham.) Glassman. & 14 & $\mathrm{P}$ & $\mathrm{Z}$ & 56 & 0.98 & 9 & 1.31 & 0.49 & 2.69 & 1.10 & 1.43 \\
\hline Chrysophyllum marginatum (Hook. \& Arn.) Radlk. & 13 & $\mathrm{~S}$ & $\mathrm{Z}$ & 52 & 0.91 & 10 & 1.45 & 0.99 & 1.81 & 0.00 & 0.94 \\
\hline Myrocarpus frondosus Allemão & 13 & $\mathrm{~S}$ & A & 52 & 0.91 & 11 & 1.60 & 1.52 & 0.00 & 1.37 & 0.96 \\
\hline Ocotea pulchella (Ness \& Mart.) Mez & 12 & $\mathrm{P}$ & $\mathrm{Z}$ & 48 & 0.84 & 7 & 1.02 & 3.72 & 4.81 & 1.37 & 3.30 \\
\hline Cordia americana (L.) Gottschling \& J.E.Mill. & 11 & $\mathrm{C}$ & A & 44 & 0.77 & 8 & 1.16 & 0.71 & 1.60 & 0.46 & 0.92 \\
\hline Annona rugulosa (Schltdl.) H.Rainer & 10 & $\mathrm{P}$ & $\mathrm{Z}$ & 40 & 0.70 & 8 & 1.16 & 0.98 & 0.73 & 0.91 & 0.87 \\
\hline Cordyline spectabilis Kunth \& Bouché & 10 & $\mathrm{~S}$ & $\mathrm{Z}$ & 40 & 0.70 & 7 & 1.02 & 0.49 & 1.76 & 0.46 & 0.90 \\
\hline not identified & 10 & - & - & 40 & 0.70 & 8 & 1.16 & 0.65 & 1.45 & 0.91 & 1.00 \\
\hline Ruprechtia laxiflora Meisn. & 10 & S & A & 40 & 0.70 & 8 & 1.16 & 0.93 & 0.73 & 0.46 & 0.70 \\
\hline Casearia sylvestris $\mathrm{Sw}$. & 9 & $\mathrm{~S}$ & Z & 36 & 0.63 & 7 & 1.02 & 0.81 & 0.73 & 0.91 & 0.82 \\
\hline Clethra scabra Pers. & 9 & $\mathrm{~S}$ & A & 36 & 0.63 & 4 & 0.58 & 0.67 & 0.00 & 0.84 & 0.50 \\
\hline Cordiera concolor (Cham). Kuntze & 9 & $\mathrm{C}$ & $\mathrm{Z}$ & 36 & 0.63 & 4 & 0.58 & 0.83 & 0.36 & 0.46 & 0.55 \\
\hline Cedrela fissilis Vell. & 8 & $\mathrm{~S}$ & A & 32 & 0.56 & 4 & 0.58 & 0.33 & 0.73 & 1.29 & 0.78 \\
\hline Myrcia oblongata D.C. & 8 & $\mathrm{P}$ & $\mathrm{Z}$ & 32 & 0.56 & 4 & 0.58 & 0.67 & 0.36 & 0.46 & 0.50 \\
\hline Nectandra lanceolata Nees & 8 & $\mathrm{~S}$ & $\mathrm{Z}$ & 32 & 0.56 & 5 & 0.73 & 0.77 & 0.36 & 0.46 & 0.53 \\
\hline Casearia obliqua Spreng. & 6 & $\mathrm{~S}$ & $\mathrm{Z}$ & 24 & 0.42 & 4 & 0.58 & 0.33 & 0.00 & 1.29 & 0.54 \\
\hline Celtis iguanaea (Jacq.) Sarg. & 6 & $\mathrm{P}$ & $\mathrm{Z}$ & 24 & 0.42 & 3 & 0.44 & 0.34 & 0.36 & 0.46 & 0.39 \\
\hline Eugenia uniflora L. & 5 & $\mathrm{~S}$ & $\mathrm{Z}$ & 20 & 0.35 & 3 & 0.44 & 0.38 & 0.52 & 0.00 & 0.30 \\
\hline Machaerium stipitatum Vogel & 5 & $\mathrm{~S}$ & A & 20 & 0.35 & 4 & 0.58 & 0.49 & 0.00 & 0.91 & 0.47 \\
\hline Myrsine loefgrenii (Mez) Imkhan. & 5 & $S$ & $\mathrm{Z}$ & 20 & 0.35 & 3 & 0.44 & 0.22 & 1.09 & 0.00 & 0.44 \\
\hline Peltophorum dubium (Spreng.) Taub & 5 & $\mathrm{P}$ & A & 20 & 0.35 & 2 & 0.29 & 0.28 & 0.36 & 0.46 & 0.37 \\
\hline Zanthoxylum rhoifolium Lam. & 5 & $\mathrm{~S}$ & Z & 20 & 0.35 & 4 & 0.58 & 0.49 & 0.00 & 0.65 & 0.38 \\
\hline Apuleia leiocarpa (Vogel) J.F.Macbr. & 4 & $\mathrm{P}$ & $\mathrm{A}$ & 16 & 0.28 & 1 & 0.15 & 0.22 & 0.00 & 0.65 & 0.29 \\
\hline Ateleia glazioveana Baill. & 4 & $\mathrm{P}$ & A & 16 & 0.28 & 2 & 0.29 & 0.38 & 0.00 & 0.46 & 0.28 \\
\hline Banara tomentosa Clos & 4 & $\mathrm{~S}$ & $\mathrm{Z}$ & 16 & 0.28 & 4 & 0.58 & 0.33 & 0.36 & 0.46 & 0.38 \\
\hline Campomanesia guazumifolia (Cambess.) O.Berg & 4 & $\mathrm{~S}$ & $\mathrm{Z}$ & 16 & 0.28 & 3 & 0.44 & 0.49 & 0.00 & 0.46 & 0.31 \\
\hline Eugenia ramboi D.Legrand & 4 & $\mathrm{~S}$ & $\mathrm{Z}$ & 16 & 0.28 & 3 & 0.44 & 0.55 & 0.00 & 0.00 & 0.18 \\
\hline Inga virescens Benth. & 4 & $\mathrm{~S}$ & $\mathrm{Z}$ & 16 & 0.28 & 4 & 0.58 & 0.65 & 0.00 & 0.00 & 0.22 \\
\hline Mollinedia triflora (Spreng.) Tul. & 4 & $S$ & $\mathrm{Z}$ & 16 & 0.28 & 4 & 0.58 & 0.33 & 0.36 & 0.46 & 0.38 \\
\hline Solanum mauritianum Scop. & 4 & $\mathrm{~S}$ & $\mathrm{Z}$ & 16 & 0.28 & 2 & 0.29 & 0.22 & 0.73 & 0.00 & 0.32 \\
\hline Styrax leprosus Hook. \& Arn. & 4 & $\mathrm{~S}$ & $\mathrm{Z}$ & 16 & 0.28 & 4 & 0.58 & 0.65 & 0.00 & 0.00 & 0.22 \\
\hline
\end{tabular}




\begin{tabular}{|c|c|c|c|c|c|c|c|c|c|c|c|}
\hline Species & $\mathrm{N}$ & SG & DS & AD & RD & $\mathrm{AF}$ & RF & NRC1 & NRC2 & NRC3 & TNR \\
\hline Annona neosalicifolia H.Rainer & 3 & $\mathrm{P}$ & $\mathrm{Z}$ & 12 & 0.21 & 2 & 0.29 & 0.33 & 0.36 & 0.00 & 0.23 \\
\hline Ilex brevicuspis Reissek & 3 & S & Z & 12 & 0.21 & 2 & 0.29 & 0.00 & 0.73 & 0.46 & 0.39 \\
\hline Machaerium paraguariense Hassl. & 3 & $\mathrm{~S}$ & A & 12 & 0.21 & 3 & 0.44 & 0.16 & 0.73 & 0.00 & 0.30 \\
\hline Miconia cinerascens $\mathrm{Miq}$ & 3 & $\mathrm{P}$ & $\mathrm{Au}$ & 12 & 0.21 & 3 & 0.44 & 0.49 & 0.00 & 0.00 & 0.16 \\
\hline Myrsine coriacea (Sw.) R.Br. ex Roem. \& Schult. & 3 & $\mathrm{P}$ & $\mathrm{Z}$ & 12 & 0.21 & 3 & 0.44 & 0.49 & 0.00 & 0.00 & 0.16 \\
\hline Strychnos brasiliensis Mart. & 3 & S & $\mathrm{Z}$ & 12 & 0.21 & 3 & 0.44 & 0.16 & 0.36 & 0.46 & 0.33 \\
\hline Zanthoxylum fagara (L.) Sarg. & 3 & S & $\mathrm{Z}$ & 12 & 0.21 & 2 & 0.29 & 0.38 & 0.00 & 0.00 & 0.13 \\
\hline Zanthoxylum petiolare A.St-Hil. \& Tul & 3 & S & $\mathrm{Z}$ & 12 & 0.21 & 3 & 0.44 & 0.49 & 0.00 & 0.00 & 0.16 \\
\hline Albizia edwallii (Hoehne) Barneby \& J.W.Grimes & 2 & S & A & 8 & 0.14 & 1 & 0.15 & 0.00 & 0.36 & 0.46 & 0.27 \\
\hline Albizia niopoides (Spruce ex Benth.) Burkart & 2 & $\mathrm{P}$ & A & 8 & 0.14 & 2 & 0.29 & 0.33 & 0.00 & 0.00 & 0.11 \\
\hline Araucaria angustifolia (Bertol.) Kuntze & 2 & $\mathrm{P}$ & $\mathrm{Z}$ & 8 & 0.14 & 2 & 0.29 & 0.33 & 0.00 & 0.00 & 0.11 \\
\hline Balfourodendron riedelianum (Engl.) Engl. & 2 & S & A & 8 & 0.14 & 2 & 0.29 & 0.33 & 0.00 & 0.00 & 0.11 \\
\hline Brunfelsia cuneifolia J.A.Schmidt & 2 & $\mathrm{P}$ & Z & 8 & 0.14 & 2 & 0.29 & 0.16 & 0.00 & 0.46 & 0.21 \\
\hline Chrysophyllum gonocarpum (Mart. \& Eichler ex Miq.) Engl. & 2 & S & $\mathrm{Z}$ & 8 & 0.14 & 1 & 0.15 & 0.00 & 0.00 & 0.65 & 0.22 \\
\hline Erythoxylum deciduum A.St.-Hil. & 2 & S & $\mathrm{Z}$ & 8 & 0.14 & 2 & 0.29 & 0.33 & 0.00 & 0.00 & 0.11 \\
\hline Erythroxylum myrsinites Mart & 2 & S & $\mathrm{Z}$ & 8 & 0.14 & 2 & 0.29 & 0.33 & 0.00 & 0.00 & 0.11 \\
\hline Eugenia involucrata DC. & 2 & S & $\mathrm{Z}$ & 8 & 0.14 & 2 & 0.29 & 0.33 & 0.00 & 0.00 & 0.11 \\
\hline Myrcianthes gigantea (D.Legrand). D.Legrand & 2 & S & $\mathrm{Z}$ & 8 & 0.14 & 2 & 0.29 & 0.33 & 0.00 & 0.00 & 0.11 \\
\hline Myrsine umbellata Mart. & 2 & S & $\mathrm{Z}$ & 8 & 0.14 & 2 & 0.29 & 0.16 & 0.00 & 0.46 & 0.21 \\
\hline Picrasma crenata (Vell.) Engl. & 2 & S & $\mathrm{Z}$ & 8 & 0.14 & 2 & 0.29 & 0.33 & 0.00 & 0.00 & 0.11 \\
\hline Psychotria suterella Müll.Arg. & 2 & - & A & 8 & 0.14 & 1 & 0.15 & 0.22 & 0.00 & 0.00 & 0.07 \\
\hline Sapium glandulosum (L.) Morong & 2 & $\mathrm{P}$ & $\mathrm{Z}$ & 8 & 0.14 & 2 & 0.29 & 0.16 & 0.00 & 0.46 & 0.21 \\
\hline Symplocos pentandra (Mattos) Occhioni ex Aranha & 2 & S & $\mathrm{Z}$ & 8 & 0.14 & 2 & 0.29 & 0.00 & 0.36 & 0.46 & 0.27 \\
\hline Trichilia catigua A.Juss & 2 & $\mathrm{C}$ & $\mathrm{Z}$ & 8 & 0.14 & 2 & 0.29 & 0.16 & 0.00 & 0.46 & 0.21 \\
\hline Aegiphila brachiata Vell. & 1 & S & Z & 4 & 0.07 & 1 & 0.15 & 0.00 & 0.36 & 0.00 & 0.12 \\
\hline Brunfelsia pilosa Plowman & 1 & $\mathrm{P}$ & $\mathrm{Z}$ & 4 & 0.07 & 1 & 0.15 & 0.00 & 0.36 & 0.00 & 0.12 \\
\hline Cabralea canjerana (Vell.) & 1 & S & $\mathrm{Z}$ & 4 & 0.07 & 1 & 0.15 & 0.16 & 0.00 & 0.00 & 0.05 \\
\hline Cordia ecalyculata Vell. & 1 & S & A & 4 & 0.07 & 1 & 0.15 & 0.16 & 0.00 & 0.00 & 0.05 \\
\hline Dalbergia frutescens (Vell.) Britton & 1 & S & A & 4 & 0.07 & 1 & 0.15 & 0.16 & 0.00 & 0.00 & 0.05 \\
\hline Eugenia burkartiana (D.Legrand) D.Legrand & 1 & $\mathrm{C}$ & $\mathrm{Z}$ & 4 & 0.07 & 1 & 0.15 & 0.16 & 0.00 & 0.00 & 0.05 \\
\hline Ilex microdonta Reissek & 1 & S & Z & 4 & 0.07 & 1 & 0.15 & 0.00 & 0.36 & 0.00 & 0.12 \\
\hline Maytenus aquifolia Mart. & 1 & - & $\mathrm{Z}$ & 4 & 0.07 & 1 & 0.15 & 0.16 & 0.00 & 0.00 & 0.05 \\
\hline Mimosa scabrella Benth. & 1 & S & A & 4 & 0.07 & 1 & 0.15 & 0.16 & 0.00 & 0.00 & 0.05 \\
\hline Myrceugenia glaucescens (Cambess.) D.Legrand \& Kausel & 1 & S & $\mathrm{Z}$ & 4 & 0.07 & 1 & 0.15 & 0.00 & 0.36 & 0.00 & 0.12 \\
\hline Myrcia hatschbachii D.Legrand & 1 & S & $\mathrm{Z}$ & 4 & 0.07 & 1 & 0.15 & 0.16 & 0.00 & 0.00 & 0.05 \\
\hline Picramnia parvifolia Engl. & 1 & S & $\mathrm{Z}$ & 4 & 0.07 & 1 & 0.15 & 0.16 & 0.00 & 0.00 & 0.05 \\
\hline Roupala asplenioides Sleume & 1 & S & $\mathrm{Z}$ & 4 & 0.07 & 1 & 0.15 & 0.16 & 0.00 & 0.00 & 0.05 \\
\hline Rudgea parquioides (Cham.) Mull.Arg. & 1 & S & A & 4 & 0.07 & 1 & 0.15 & 0.16 & 0.00 & 0.00 & 0.05 \\
\hline Sambucus australis Cham. \& Schltdl. & 1 & $\mathrm{P}$ & $\mathrm{Z}$ & 4 & 0.07 & 1 & 0.15 & 0.16 & 0.00 & 0.00 & 0.05 \\
\hline Schaefferia argentinensis Speg. & 1 & S & $\mathrm{Z}$ & 4 & 0.07 & 1 & 0.15 & 0.16 & 0.00 & 0.00 & 0.05 \\
\hline Schinus terebinthifolius Raddi & 1 & $\mathrm{P}$ & $\mathrm{Au}$ & 4 & 0.07 & 1 & 0.15 & 0.00 & 0.36 & 0.00 & 0.12 \\
\hline Vernonanthura discolor (Spreng.) H.Rob & 1 & $\mathrm{P}$ & A & 4 & 0.07 & 1 & 0.15 & 0.00 & 0.00 & 0.46 & 0.15 \\
\hline Xylosma pseudosalzmanii Sleumer & 1 & S & $\mathrm{Z}$ & 4 & 0.07 & 1 & 0.15 & 0.16 & 0.00 & 0.00 & 0.05 \\
\hline Total & 1425 & & & 5700 & 100 & & 100 & 100 & 100 & 100 & 100 \\
\hline
\end{tabular}

exclusive to natural regeneration (17) are rare locally, presenting mostly one individual. Most of the exclusive species (12) are secondary, which indicates that they are finding favorable conditions for germination and establishment in the PEAR. The absence of Dicksonia sellowiana Hook. and Alsophila setosa Kaulf. should be highlighted in the regenerating component.

The most frequent dispersal syndrome was the zoochory with $71 \%$ of the species and 1,157 individuals, followed by anemochory ( $23 \%$ and 222 individuals) and autochory ( $4 \%$ and 36 individuals). As for the successional category, $65 \%$ of the species are secondary, $25 \%$ pioneer, $7 \%$ climax and $3 \%$ without information (Table 1).

In the class $1,3,340$ ind ha- ${ }^{-1}$ were sampled, belonging to 89 species and 35 families; in the class 2, 1,304 ind ha ${ }^{-1}, 56$ species and 26 families; and in the class 3 , 1,056 ind ha ${ }^{-1}, 58$ species and 26 families. There was a reduction in the number of 
individuals from the class 1 to class 3 (Fig. 2), but there was a reduction in the number of species only from the class 1 to the other classes.

Regarding the size classes, $41 \%$ of the species occurred in all size classes. Twenty-nine species occurred only in class 1 , five species were sampled only in class 2 and Vernonanthura discolor (Spreng.) H.Rob. occurred exclusively in class 3. However, this species is rare locally in natural regeneration with only one individual. TNR values ranged from 0.05 to $8.12 \%$ (Table 1), with emphasis on Trichilia elegans, Nectandra megapotamica, Coussarea contracta and Cupania vernalis with TNR values greater than $6 \%$ (Fig. 3). Araucaria angustifolia showed an absolute density of 8 ind ha ${ }^{-1}$, all sampled in class 1 and, TNR of only $0.11 \%$ (Table 1 ).

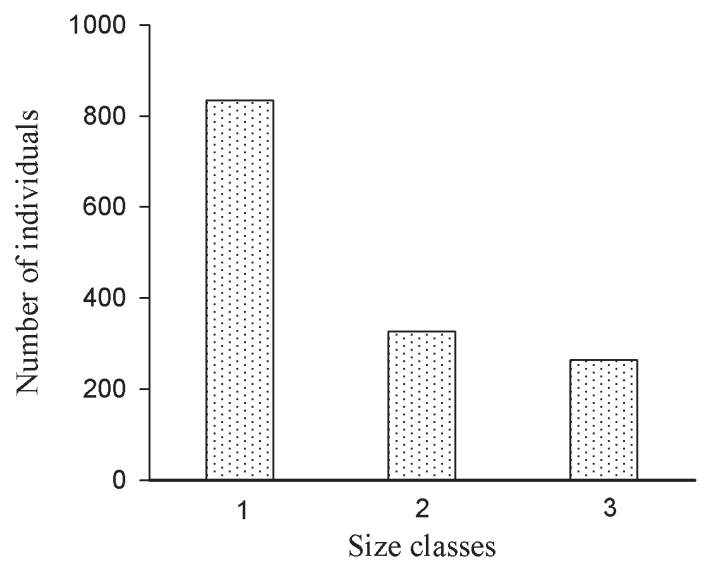

Figure 2. Number of individuals by size classes of tree natural regeneration in Parque Estadual das Araucárias, Santa Catarina, southern Brazil. Class $1=$ height between $1.0 \mathrm{~m}$ and $2.0 \mathrm{~m}$; class $2=$ height between $2.01 \mathrm{~m}$ and $3.0 \mathrm{~m}$; class $3=$ height above $3.0 \mathrm{~m}$ and diameter at breast height less than $5 \mathrm{~cm}$.

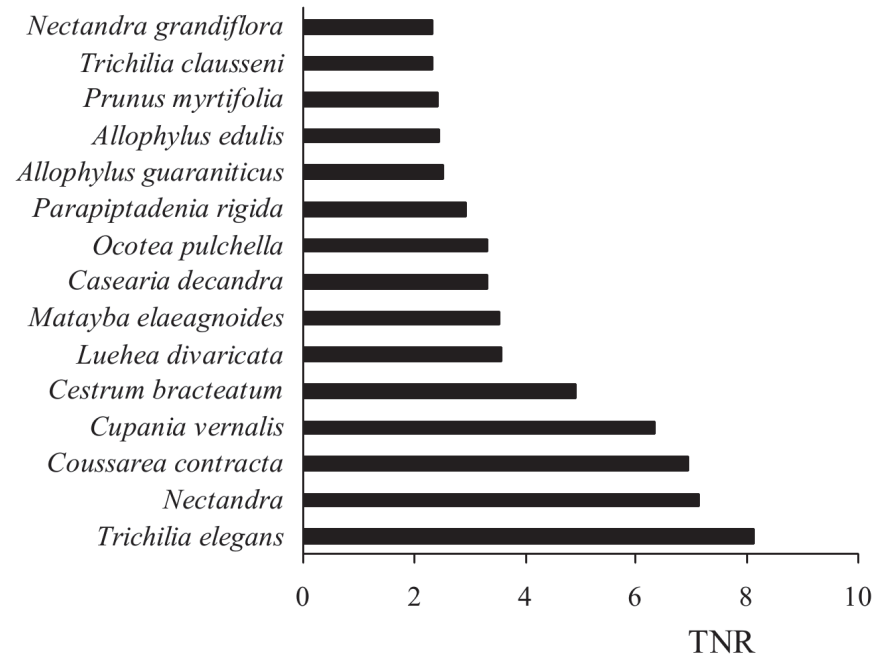

Figure 3. Species with the highest rates of potential total natural regeneration (TNR (\%)) in the Parque Estadual das Araucárias, Santa Catarina, southern Brazil. 


\section{Discussion}

The study area underwent logging for decades (Fatma 2015). In the most disturbed sites, the lower stratum is composed of shrub species, lianas and, in some cases, native bamboo. In places with less light incidence on the forest floor and with higher humidity, well-defined understory and the occurrence of shade-tolerant species were observed. Therefore, PEAR is characterized as a successional mosaic, with different stages of regeneration. This corroborates the large number of secondary and pioneer species sampled in the study.

As for families with greater specific richness, studies have shown that the MOF tends to follow a floristic pattern, with emphasis on Myrtaceae and Lauraceae (Mauhs and Backes 2002; Souza et al. 2012; Fiorentin et al. 2015; Higuchi et al. 2015; Santos et al. 2015). Generally, a large number of Fabaceae species in MOF is not common (Fiorentin et al. 2015; Santos et al. 2015; Higuchi et al. 2016) and it is often found with greater richness in seasonal forests (Jarenkow and Waechter 2001). Unlike the present study, in the Inventário Florístico Florestal de Santa Catarina (IFF$\mathrm{SC}$ ), the Fabaceae family was the fourth most numerous, with 20 species in regeneration (Meyer et al. 2013). In the floristic and phytosociological survey of the tree strata carried out at PEAR (Passos et al. 2021), the families with the highest specific richness were also Fabaceae (14 spp.), followed by Lauraceae and Myrtaceae (8 spp.).

The regenerating component showed high similarity with the PEAR tree component (Passos et al. 2021). However, in the regenerating component, the absence (Dicksonia sellowiana and Alsophila setosa) or low density (A. angustifolia and Ateleia glazioveana Baill.) of species that showed high values of importance in the tree component (Passos et al. 2021) were recorded. The diversity of regenerating species in the PEAR was greater than that recorded in other studies of MOF (Caldato et al. 1996; Mauhs and Backes 2002; Narvaes et al. 2005; Fiorentin et al. 2015; Santos et al. 2015), similar to the diversity described by Maçaneiro et al. (2016) and inferior to that observed by Meyer et al. (2013). Equability in the PEAR is relatively high, as the existence of a few highly dominant species in the sample was verified, in agreement with what was reported by Maçaneiro et al. (2016).

Among the five species best positioned in the density ranking in the regenerating component of PEAR, only Cupania vernalis, Casearia decandra and Matayba elaeagnoides are common with those best positioned in other fragments of MOF in the south of SC (Higuchi et al. 2015; Santos et al. 2015; Maçaneiro et al. 2016; Duarte et al. 2019) and in Rio Grande do Sul state (Silva et al. 2010a). There was also no coincidence between the 10 species with the highest rate of natural regeneration between this and the study of regeneration in upper montane MOF in SC (Rosa et al. 2016). These studies demonstrate the great floristic and structural variation in the regenerating tree component among the several fragments of MOF in Brazil, and emphasize the importance of them for the restoration projects of MOF throughout its natural range.

Among the species with the highest density and frequency in the regenerating component, $N$. megapotamica stood out, which had already been highlighted in the PEAR tree stratum, forming an association with A. angustifolia (Passos et al. 2021). 
This was expected, since western SC is characterized by an abundance of Lauraceae, with significant occurrence of N. lanceolata, N. megapotamica and Ocotea puberula (Klein 1978). Nectandra megapotamica was the most abundant species in the study on the dynamics of regeneration in fragments of MOF in the southern plateau of Santa Catarina (Vefago et al. 2019). This species occurs inside the forest, where high regeneration is found (second highest rate of TNR in the PEAR), which suggests that the species is in full dynamic balance. Because it is a shade-tolerant species, its installation begins in secondary vegetation (Reitz et al. 1983), which justifies its presence in different areas of the PEAR. This species also stands out in the southern portion of the Atlantic Forest, due to its high geographical range, abundance and different habitats in which they occur (Caiafa and Martins 2010; Fontana et al. 2016). Nectandra megapotamica presented the highest density and frequency in the PEAR tree component (Passos et al. 2021), in addition to being recorded with high abundance and importance value in other studies (Mauhs and Backes 2002; Bianchini et al. 2003; Callegaro et al. 2015).

Similar to the tree component (Passos et al. 2021), secondary and zoochorous species predominated in the regenerating component. The dispersal syndrome data are similar to those of natural regeneration in fragments of MOF in Paraná (Rondon-Neto et al. 2001) and Santa Catarina states (Negrini et al. 2012). The large proportion of zoochorous species in MOF supports the importance of animals for the dispersal of propagules and, consequently, for the maintenance of the gene flow of forests (Almeida et al. 2008).

The values recorded for the TNR in the PEAR were lower than those observed by Caldato et al. (1996) (2.51 to 15.01\%), and close to those observed by Mauhs and Backes (2002) ( 0 a 9.59\%). Comparing the 20 highest positioned species in the tree component, ordered by the importance value (Passos et al. 2021) with those of the regenerating component (ordered by TNR), 12 were common. Therefore, it is expected that there will be no major structural or floristic changes in the PEAR, as long as environmental and conservation conditions are maintained.

Considering natural regeneration as a whole, $41 \%$ of species occurred in all height classes. These species, with more regular distribution in the different growth phases, are more likely to compose the forest structure in the future (Caldato et al. 1996). The reduction in the number of species for the larger classes may be related to the characteristics of the life history of these species, such as the variation in shade tolerance at different stages of the life cycle. Among the factors that influenced the distribution of regenerating species in the MOF is the variation related to the canopy opening (Duarte et al. 2019), and studies have shown that the luminosity variation within the forest influences the species distribution (Higuchi et al. 2015; Duarte et al. 2019). Therefore, the history of PEAR exploitation and canopy disturbances caused by climatic events could justify the floristic differences between PEAR and other studies of MOF regeneration (Caldato et al. 1996; Higuchi et al. 2015; Santos et al. 2015; Duarte et al. 2019). Despite the presence of $41 \%$ of the species in the three size classes, of the 99 species surveyed in this study, 74 have TNR less than 1.0, indicating that these species may have a higher degree of difficulty to regenerate in the future (Silva et al. 2010b). 
Trichilia elegans showed the highest TNR (8.12\%), mainly because the species obtained the highest NRC in classes 2 and 3. In one of the plots sampled in the PEAR by the IFFSC (Meyer et al. 2013), the presence of T. elegans in the regenerating component was also highlighted. In the understory of seasonal forests, the presence of species of the genus Trichilia is common (Bianchini et al. 2003; Souza and Lorenzi 2012).

The low value of TNR for A. angustifolia is consistent with other studies (Caldato et al. 1996; Narvaes et al. 2005; Silva et al. 2010a; Kanieski et al. 2012; Vefago et al. 2019). The absence of juveniles indicates that this species, being a heliophile, does not find favorable conditions for its establishment due to shading (Caldato et al. 1996; Souza et al. 2008; Vefago et al. 2019). Therefore, the establishment of seedlings only occurs in the initial stages of succession (Mauhs and Backes 2002) and, in PEAR, the natural regeneration of the species was recorded only in the border plots or in gap. Paludo et al. (2011) observed that the critical stage for the regeneration of the species was in the first years of development (up to $0.5 \mathrm{~m}$ in height). However, as the species is long-lived, it can maintain a low number of regenerating individuals in the population and, even so, be successful in regeneration (Paludo et al. 2011). In a study using the Matrix Model, it was found that the recruitment of A. angustifolia was insufficient to replace the reproductive individuals and, therefore, the population was in a self-thinning phase (the elimination of dominated individuals due to competition), in accord to Lozenge model (Paludo et al. 2016). According to this model, the population is expected to regenerate in the future, but the species exhibits declining stability, which aggravates the endangerment situation (Paludo et al. 2016).

Another issue to be considered may be the reduction in the number of propagules and young individuals of $A$. angustifolia in the PEAR. Despite the presence of reproductive adults, park rangers and researchers have observed the ringing of the stem of young plants, which can lead to death for the individual, as well as the large amount of pine cones with immature seeds on the forest floor. One of those responsible for these practices (already registered by park rangers) is Sapajus nigritus Goldfuss, 1809 (capuchin monkey), which has a high population density in the PEAR (Alves 2008). The consumption of the terminal part of the stem of young individuals of Syagrus romanzoffiana by these animals was also observed (field observation). Specific studies on these interactions are necessary in order to support management practices in the PEAR. In addition, studies suggest the implementation of silvicultural treatments and enrichment plantation that benefit the development of A. angustifolia (Narvaes et al. 2005; Kanieski et al. 2012).

On the other hand, Klein (1978) suggested a trend of expansion of the seasonal deciduous forest over the MOF, due to the low regeneration of A. angustifolia. Other species characteristic of MOF, such as Mimosa scabrella (Lorenzi 2008), also presented low potential for natural regeneration, and Ocotea porosa did not present individuals in natural regeneration. Caldato et al. (1996) also recorded low rates of natural regeneration for $O$. porosa and M. scabrella. Also noteworthy is the absence of Dicksonia sellowiana, a characteristic species of MOF, in the natural regeneration of PEAR. According to Mallmann et al. (2019), canopy cover and soil moisture are environmental factors that influence the establishment and growth of D. sellowiana. 
Specific studies should be conducted to explain the absence of these species in the regenerating component of PEAR.

In general, the high similarity between the studies of natural regeneration and the tree component indicates that the composition of the forest will suffer little change in the future if the current conditions are maintained. However, the absence or low regeneration of $A$. angustifolia, D. sellowiana and A. setosa, as well as other species of MOF, such as $O$. porosa and M. scabrella can imply important floristic changes, such as the invasion by species typical of the seasonal forest. According to Vefago et al. (2019), temperature and altitude play a relevant role in the definition of floristic identity in the MOF remnants. As the MOF distribution is positively correlated with cloudiness and frost, and inversely with temperature (Oliveira-Filho et al. 2015), it is concluded that this forest type is dependent on low temperatures and is limited by the seasonality of the climate. Analyzing the historical series of temperature for the region, there is a clear trend of an increase in temperature in the last 100 years (CRU 2016), which can impact the MOF.

\section{Conclusion}

The Parque Estadual das Araucárias, in addition to the past anthropic disturbance (logging), presents variations of relief, which favors the occurrence of different habitats. This heterogeneity of habitats made it possible to record high species richness and diversity in the tree regenerating component. However, the calculation of the estimated richness indicates that the number of species may be even greater. Because it is a protected area, the presence of park rangers and constant monitoring ensures that destructive human activities are reduced or nullified in the PEAR, allowing biodiversity to be conserved.

The low value obtained for the TNR for A. angustifolia is in agreement with the results of other studies, since it is a heliophile species. Therefore, its establishment in the interior of the forest is difficult due to the shading, and consequently, its conservation in situ is more complex.

The similarity of species between natural regeneration and the tree component indicates that, in the future, there will be little change in species composition. However, the absence (or decrease) of the regeneration of some typical species of MOF, such as A. angustifolia, in addition to climate changes, may result in a change in the area's phytophysiognomy in the future. Therefore, silvicultural treatments and enrichment plantations can be implemented in the PEAR, aiming at the conservation of typical MOF species of this region, such as Dicksonia sellowiana and Alsophila setosa. In the specific case of $A$. angustifolia, enrichment plantation in areas with the most open vegetation in the PEAR can contribute to the conservation of this species.

\section{Acknowledgements}

We thank the Fundação de Amparo à Pesquisa e Inovação no Estado de Santa Catarina (FAPESC); National Science Foundation and São Paulo State Research Support Foundation for the postdoctoral fellowship (NSF-FAPESP PIRE-CREATE project grants 
2017/50085-3 and 2019/27110-7); Specialists who assisted in the identification: Martin Grings and André Luiz de Gasper; This study was financed in part by the Coordenação de Aperfeiçoamento de Pessoal de Nível Superior (CAPES)-Brazil-Finance Code 001.

\section{References}

Almeida SR, Watzlawick LF, Myszka E, Valerio AF (2008) Florística e síndromes de dispersão de um remanescente de Floresta Ombrófila Mista em sistema faxinal. Ambiência 4(2): 289-297. https://revistas.unicentro.br/index.php/ambiencia/article/viewFile/169/210

Alvares CA, Stape JL, Sentelhas PC, Gonçalves JLM, Sparovek G (2013) Köppen's climate classification map for Brazil. Meteorologische Zeitschrift 22(6): 711-728. https://doi. org/10.1127/0941-2948/2013/0507

Alves FC (2008) Estudo populacional de Cebus nigritus (Goldfuss, 1809) no Parque Estadual das Araucárias - São Domingos, Santa Catarina. Dissertação de Mestrado, Chapecó: Universidade Comunitária Regional de Chapecó.

APG IV (2016) An update of the Angiosperm Phylogeny Group classification for the orders and families of flowering plants. Botanical Journal of the Linnean Society 181(1): 1-20. https://doi.org/10.1111/boj.12385

Backes P, Irgang B (2002) Árvores do Sul: guia de identificação e interesse ecológico - as principais espécies nativas Sul-Brasileiras. Instituto Souza Cruz, Santa Cruz do Sul, 325 pp.

Bianchini E, Popolo RS, Dias MC, Pimenta JA (2003) Diversidade e estrutura de espécies arbóreas em área alagável do município de Londrina, sul do Brasil. Acta Botanica Brasilica 17(3): 405-419. https://doi.org/10.1590/S0102-33062003000300008

Caiafa NA, Martins FR (2010) Forms of rarity of tree species in the southern Brazilian Atlantic rainforest. Biodiversity and Conservation 19(9): 2597-2618. https://doi.org/10.1007/ s10531-010-9861-6

Caldato SL, Floss PA, Croce DM, Longhi SJ (1996) Estudo da regeneração natural, banco de sementes e chuva de sementes na Reserva Genética Florestal de Caçador, SC. Ciência Florestal 6(1): 27-38. https://doi.org/10.5902/19805098323

Callegaro RM, Longhi SJ, Andrzejewski C, Araujo MM (2015) Regeneração natural de espécies arbóreas em diferentes comunidades de um remanescente de floresta ombrófila mista. Ciência Rural 45(10): 1795-1801. https://doi.org/10.1590/0103-8478cr20131098

Cientec (2006) Mata Nativa 2: Manual do Usuário. Viçosa, Cientec, 295 pp.

Colwell RK (2013) EstimateS: statistical estimation of species richness and shared species from samples. Version 9.1.0. [Disponível em:] http://viceroy.eeb.uconn.edu/estimates. [Acesso: jun. 2016]

CRU [Climatic Research Unit] (2016) CRU TS3.23: Climatic Research Unit (CRU) TimeSeries (TS) Version 3.23 of High Resolution Gridded Data of Month-by-month Variation in Climate (Jan. 1901 - Dec. 2014). [Disponível em:] http://catalogue.ceda.ac.uk/ uuid/5dca9487dc614711a3a933e44a933ad3 [Acesso: set. 2016]

Duarte SW, Hoffmann LT, Maçaneiro JP, Fenilli TAB, Schorn LA (2019) Effects of the environment and spatial factors on the regeneration of Araucaria Forest fragments, southern Brazil. Applied Ecology and Environmental Research 17(4): 9577-9589. https:// doi.org/10.15666/aeer/1704_95779589 
Fatma [Fundação de Meio Ambiente] (2015) Plano de Manejo do Parque Estadual das Araucárias - Fase 2: $1^{\text {a }}$ versão do plano revisado. Florianópolis, Apremavi.

Fiorentin LD, Téo SJ, Schneider CR, Costa RH, Batista S (2015) Análise florística e padrão espacial da regeneração natural em área de Floresta Ombrófila Mista na região de Caçador, SC. Floresta e Ambiente 22(1): 60-70. https://doi.org/10.1590/2179-8087.071413

Flora do Brasil [under construction] (2020) Lista da flora do Brasil. Jardim Botânico do Rio de Janeiro, Rio de Janeiro. http://floradobrasil.jbrj.gov.br/ [Accessed on: 09 Dec. 2020]

Fontana C, Gasper AL, Sevegnani L (2016) A raridade das espécies arbóreas de Lauraceae no planalto do Estado de Santa Catarina, Brasil. Hoehnea 43(3): 361-369. https://doi. org/10.1590/2236-8906-95/2015

Gasper AL, Sevegnani L, Vibrans AC, Sobral M, Uhlmann A, Lingner DV, Rigon Júnior MJ, Verdi M, Stival-Santos A, Dreveck S, Korte A (2013) Inventário florístico florestal de Santa Catarina: Espécies da Floresta Ombrófila Mista. Rodriguésia 64(2): 201-210. https://doi.org/10.1590/S2175-78602013000200001

Higuchi P, Silva AC, Almeida JA, Bortoluzzi RLC, Mantovani A, Ferreira TS, Souza ST, Gomes JP, Silva KM (2013) Florística e estrutura do componente arbóreo e análise ambiental de um fragmento de floresta ombrófila mista alto-montanha no município de Painel, SC. Ciência Florestal 23(1): 153-164. https://doi.org/10.5902/198050988449

Higuchi P, Silva AC, Buzzi Jr F, Negrini M, Ferreira TS, Souza ST, Santos KF, Vefago MB (2015) Fatores determinantes da regeneração natural em um fragmento de floresta com araucária no planalto catarinense. Scientia Forestalis 43(106): 251-259. https://www. ipef.br/publicacoes/scientia/nr106/cap01.pdf

Higuchi P, Silva AC, Ferreira TS, Souza ST, Gomes JP, Silva KM, Santos KF, Berndt EJ, Souza Jr JO, Gois DT, Weiduschat F (2016) Florística e estrutura do componente arbóreo e relação com variáveis ambientais em um remanescente florestal em Campos Novos SC. Ciência Florestal 26(1): 35-46. https://doi.org/10.5902/1980509821089

Jarenkow JA, Budke JC (2009) Padrões florísticos e analise estrutural de remanescentes de florestas com araucária no Brasil. In: Fonseca CR, Souza AF, Leal-Zanchet AN, Dutra T, Backes A, Ganado G (Eds) Floresta com Araucária: Ecologia, Conservação e Desenvolvimento Sustentável. Editora Holos, Ribeirão Preto, 113-126.

Jarenkow J, Waechter J (2001) Composição, estrutura e relações florísticas do componente arbóreo de uma floresta estacional no Rio Grande do Sul, Brasil. Revista Brasileira de Botanica. Brazilian Journal of Botany 24(3): 263-272. https://doi.org/10.1590/S010084042001000300004

Kanieski MR, Longhi SJ, Narvaes IS, Soares PRC, Longhi ST, Callegaro RM (2012) Diversidade e padrões de distribuição espacial de espécies no estágio de regeneração natural em São Francisco de Paula, RS, Brasil. Floresta 42(3): 509-518. https://doi.org/10.5380/rf.v42i3.25037

Klauberg C, Paludo GF, Bortoluzzi RLC, Mantovani A (2010) Florística e estrutura de um fragmento de Floresta Ombrófila Mista no Planalto Catarinense. Biotemas 23(1): 35-47. https://doi.org/10.5007/2175-7925.2010v23n1p35

Klein RM (1978) Mapa fitogeográfico de Santa Catarina. In: Reitz R (Ed.) Flora Ilustrada Catarinense. Herbário Barbosa Rodrigues, Itajaí, 24 pp.

Lorenzi H (2008) Árvores brasileiras, v.1, 5.ed. Instituto Plantarum, Nova Odessa. 
Maçaneiro JP, Seubert RC, Schorn LA (2016) Variações na composição e estrutura da vegetação permitem detectar agrupamentos logísticos em uma Floresta Subtropical Atlântica no Sul do Brasil? Biotemas 29(4): 43-58. https://doi.org/10.5007/2175-7925.2016v29n4p43

Mallmann IT, Silva VL, Port RK, Oliveira FB, Schmitt JL (2019) Spatial distribution analysis of Dicksonia sellowiana Hook. in Araucaria forest fragments with different sizes. Brazilian Journal of Biology 79(2): 337-344. https://doi.org/10.1590/1519-6984.186083

Marchesini VA, Sala OE, Austin AT (2009) Ecological consequences of a massive flowering event of bamboo (Chusquea culeou) in a temperate forest of Patagonia, Argentina. Journal of Vegetation Science 40(3): 424-432. https://doi.org/10.1111/j.1654-1103.2009.05768.x

Martins D, Rodrigues AL, Chaves CL, Mantovani A, Bortoluzii RLC (2012) Estrutura de um remanescente de Floresta Ombrófila Mista em Urupema, Santa Catarina, Brasil. Revista de Ciências Agroveterinárias 11(2): 126-137.

Mauhs J, Backes A (2002) Estrutura fitossociológica e regeneração natural de um fragmento de Floresta Ombrófila Mista exposto a perturbações antrópicas. Pesquisas, Botânica 52: 89-109. http://www.anchietano.unisinos.br/publicacoes/textos/mauhs2002/julian.pdf

Meyer L, Gasper AL, Sevegnani L, Schorn LA, Vibrans AC, Lingner DV, Verdi M, Santos AS, Dreveck S, Korte A (2013) Regeneração natural da Floresta Ombrófila Mista em Santa Catarina. In: Vibrans AC, Sevegnani L, Gasper AL, Lingner DV (Eds) Inventário Florístico Florestal de Santa Catarina: Floresta Ombrófila Mista, v 3. Edifurb, Blumenau, 191-222. https://doi.org/10.1590/S2175-78602013000300001

Mueller-Dombois DD, Ellenberg H (1974) Aims and Methods of Vegetation Ecology. John Wiley, New York, 547 pp.

Narvaes IS, Brena DA, Longhi SJ (2005) Estrutura da regeneração natural em Floresta Ombrófila Mista na Floresta Nacional de São Francisco de Paula, RS. Ciência Florestal 15(4): 331-342. https://doi.org/10.5902/198050981871

Negrini M, Aguiar MD, Vieira CT, Silva AC, Higuchi P (2012) Dispersão, distribuição espacial e estratificação vertical da comunidade arbórea em um fragmento florestal no Planalto Catarinense. Revista Árvore 36(5): 919-930. https://doi.org/10.1590/S0100-67622012000500014

Oliveira LZ, Moser P, Vibrans AC, Piazza GA, Gasper AL, Oliveira-Filho AT (2016) Insights for selecting the most suitable nonparametric species-richness estimators for subtropical Brazilian Atlantic Forests. Brazilian Journal of Botany 39(2): 593-603. https://doi. org/10.1007/s40415-016-0269-8

Oliveira-Filho AT, Budke JC, Jarenkow JA, Eisenlohr PV, Neves DRM (2015) Delving into the variations in tree species composition and richness across South American subtropical Atlantic and Pampean forests. Journal of Plant Ecology 8(3): 242-260. https:// doi.org/10.1093/jpe/rtt058

Paludo GF, Mantovani A, Klauberg C, Reis MS (2011) Estrutura demográfica e padrão espacial de uma população natural de Araucaria angustifolia (Bertol.) Kuntze (Araucariaceae), na Reserva Genética Florestal de Caçador, Estado de Santa Catarina. Revista Árvore 33(6): 1109-1121. https://doi.org/10.1590/S0100-67622009000600013

Paludo GF, Lauterjung MB, Reis MS, Mantovani A (2016) Inferring population trends of Araucaria angustifolia (Araucariaceae) using a transition matrix model in an old-growth forest. Southern Forests 78(2): 137-143. https://doi.org/10.2989/20702620.2015.1136506 
Passos MG, Prado GP, Fontana C, Bianchini E (2021) Structure and tree diversity in a Mixed Ombrophilous Forest remnant, southern Brazil. Floresta e Ambiente 28(2): e20200064. https://doi.org/10.1590/2179-8087-floram-2020-0064

Reitz R, Klein RM, Reis A (1983) Projeto madeira do Rio Grande do Sul. Sellowia 34/35: $1-525$.

Rondon-Neto RM, Watzlawick LF, Caldeira MVW (2001) Diversidade florística e síndromes de dispersão de diásporos das espécies arbóreas de um fragmento de Floresta Ombrófila Mista. Revista Ciências Exatas e Naturais 3(2): 209-216. https://revistas.unicentro.br/ index.php/RECEN/article/view/484

Rosa AD, Silva AC, Hguchi P, Marcon AK, Missio FF, Bento MA, Silva JO, Gonçalves DA, Rodrigues Júnior LC (2016) Natural regeneration of tree species in a cloud forest in Santa Catarina, Brazil. Revista Árvore 40(6): 1073-1082. https://doi.org/10.1590/010067622016000600013

Santa Catarina (1986) Números de Santa Catarina. Gaplan, Florianópolis.

Santos KF, Ferreira TS, Higuchi P, Silva AC, Vandresen PB, Costa A, Spada G, Schmitz V, Souza F (2015) Regeneração natural do componente arbóreo após a mortalidade de um maciço de taquara em um fragmento de floresta ombrófila mista em Lages - SC. Ciência Florestal 25(1): 107-117. https://doi.org/10.5902/1980509817467

Schorn LA, Gasper AL, Meyer L, Vibrans AC (2013) Síntese da estrutura dos remanescentes florestais em Santa Catarina. In: Vibrans AC, Sevegnani L, Gasper A, Lingner RDV (Eds) Inventário florístico Florestal de Santa Catarina. Edifurb, Blumenau, 125-137.

Silva MM, Ganade GMS, Backes A (2010a) Regeneração natural em um remanescente de Floresta Ombrófila Mista, na Floresta Nacional de São Francisco de Paula, Rio Grande do Sul, Brasil. Pesquisas, Botânica 61: 259-278. http://www.anchietano.unisinos.br/ publicacoes/botanica/botanica61/09.pdf

Silva WC, Marangon LC, Ferreira RLC, Feliciano ALP, Aparício OS, Costa Jr RF (2010b) Estrutura horizontal e vertical do componente arbóreo em fase de regeneração natural na mata Santa Luzia, no município de Catende-PE. Revista Árvore 34(5): 863-869. https://doi.org/10.1590/S0100-67622010000500011

Souza VC, Lorenzi H (2012) Botânica sistemática: guia ilustrado para identificação das famílias de Angiospermas da flora brasileira, baseado em APG III. Instituto Plantarum, Nova Odessa.

Souza AF, Forgiari C, Longhi SJ, Brena DA (2008) Regeneration patterns of a long-lived dominant conifer and the effects of logging in southern South America. Acta Oecologica 34(2): 221-232. https://doi.org/10.1016/j.actao.2008.05.013

Souza RPM, Souza VC, Polisel RT, Ivanauskas NM (2012) Estrutura e aspectos da regeneração natural de Floresta Ombrófila Mista no Parque Estadual de Campos do Jordão, SP, Brasil. Hoehnea 39(3): 387-407. https://doi.org/10.1590/S2236-89062012000300004

Thiers B (2021) Index herbariorum: a global directory of public herbaria and associated staff. New York Botanical Garden's Virtual Herbarium. http://sweetgum.nybg.org/science/ih/ [Accessed on 03.01.2021]

Van der Pijl L (1982) Principles of dispersal in higher plants ( $3^{\text {rd }}$ ed.). Springer Verlag, Berlin. https://doi.org/10.1007/978-3-642-87925-8 
Vefago MB, Silva AC, Cuchi T, Santos GN, Nunes AS, Rodrigues Júnior LC, Lima CL, Gross A, Kilca RV, Higuchi P (2019) What explains the variation on the regenerative component dynamics of Araucaria Forests in southern Brazil? Scientia Agrícola 76(5): 405-414. https://doi.org/10.1590/1678-992x-2017-0304

Volpato MML (1994) Regeneração natural de uma floresta secundária no domínio de Mata Atlântica: uma análise fitossociológica. Dissertação de Mestrado, Viçosa: Universidade Federal de Viçosa. 